\title{
Changing Employment Relations in the Asia-Pacific Region
}

\author{
Greg Bamber \\ Griffith University \\ Chris Leggett \\ University of South Australia
}

\begin{abstract}
This paper compares the employment relations of Australia; Indonesia; Japan; New Zealand; the Peoples' Republic of China (PRC); South Korea; and Taiwan (Republic of China, ROC). The inclusion of the older industrialised economies of Australia, New Zealand and Japan with the industrialising and newly industrialised countries of Asia enables comparisons of labour market restructuring for increased flexibility. In South Korea the process of democratisation has included a reduction in state regulation of trade unions. In Taiwan the same process has led government to become more active in employment relations, and the PRC's transition from a highly regulated to a 'socialist market' economy has had a noticeable effect on employment relations too. In Indonesia, the end of the Soharto regime might have offered opportunities for greater recognition of workers' interests, but political instability and the effect of the 1997 Asian economic crisis seem to have inhibited this development.
\end{abstract}

\section{Introduction}

Before reviewing the changing employment relations in the Asia-Pacific region, we discuss the possible links between industrialisation, democratisation and employment relations in the Asia Pacific region. First, some clarification of the use of these terms is in order. As a discipline of study employment relations encompasses the various methods and processes of people management, including rules, attitudes and behaviour within and around employment in work. Thus it includes the institutions of industrial relations: employees and their organisations, employers and their associations, and the state and its departments with labour portfolios as well as the objective (as opposed to the prescriptive) phenomena of human resource management (HRM). ${ }^{1}$

Both transformation and democratisation have been used indiscriminately in the literature. Transformation can mean a change in appearance or a complete change in character, i.e. a fundamental change (OED 1973). The latter can be seen in some countries. However, it is necessary to keep in mind the continuities in employment relations arrangements, and the exaggerations which, for political or commercial motives, may be made of the extent of change. Democratisation is the movement towards 'government by the people' which may involve 'direct' or more usually 'indirect' representation (Elliott 1969: 120) or 'government where control and power rests [sic] in the majority of the people [but implying] that the rights of the minority will be respected' (Roberts 1986: 143). While democratisation can occur at both micro and macro levels, many employment relations analysts tend to concentrate on the former, especially on economic and industrial democracy and employee participation in union and management decisions, perhaps through works councils and/or collective bargaining (Clegg 1960). However, with micro-economic reform on political agendas over the past two decades the study of the micro-level has assumed increased importance.

When attempts were made to install democracy in Japan after 1945, particular attention was paid to employment relations, especially to trade unionism, which American New Dealers in the occupying powers' administration saw as a countervailing force to totalitarianism. Elsewhere in the Asia-Pacific region, notably in South Korea, before the Cold War set in there were US-led moves to democratise, but a subsequent roll back of militant trade unionism and leftist political parties helped to transform employment relations in a different direction. Militant Japanese trade unionism declined following the failure of the Miike coalminers' strike in 1960 to be displaced by a more economically

\footnotetext{
${ }^{1}$ For a diverse selection of introductions to the field, albeit from the perspective of English-speaking industrialised market economies (IMEs), see Bamber and Lansbury (1998) and, from the US: Katz and Kochan (1992); Dunlop (1993); from Australia: Gardner and Palmer (1997); from Canada: Chaykowski and Verma (1992); and from Britain: Gospel and Palmer (1993).
} 
oriented trade unionism. The South Korean union organisation, Chun Pyung, which had been banned in 1947 was superseded by Daehan Dogrib Chockseong Nodong, the precursor of South Korea's Daehan Nochong or Federation of Korean Trade Unions (FKTU) which, until 1997, remained the only officially recognised peak body.

Since the ending of the Cold War we can discern the growing autonomy of unions in various countries in the region as they have countered their governments' attempts to control them. Since the mid-1990s, Minju Nochong or the Korean Confederation of Trade Unions (KCTU) has challenged the legitimacy of the government-approved FKTU, and campaigned for the recognition of the teachers' union, Chonkyojo. In Indonesia, from the early 1990s, Serikat Buruh Sejahtera Indonesia or the Indonesian Prosperous Workers' Union (SBSI) has attempted to rival the pro-government Serikat Pekerja Seluruh Indonesia or All Indonesia Workers' Union (SPSI).

The re-emergence of independent labour movements in parts of the Asia-Pacific was tested by the 'Asian crisis' of the late 1990s. During periods of recession and rising unemployment, unions generally face a difficult task in gaining concessions from employers and governments. In Indonesia, the enforcement of labour standards continues to be weak, but the government did release the leader of the independent trade unions from detention and ratified the International Labour Organisation (ILO) Convention 87 on freedom of association (US Department of State 1999: 905). However, in spite of vigorous protests by South Korean unions the large Korean business conglomerates or chaebol were enabled by labour law amendments, to retrench substantial numbers of workers in the late 1990s.

External pressures to improve human and trade union rights in the Asia-Pacific region have paralleled the promotion of democratisation. For example, in 1998, the ILO adopted a 'Declaration on Fundamental Principles and Rights to Work' which reaffirmed ILO members' obligations to promote and respect, among other standards, freedom of association, the right to organise and bargain collectively and non-discrimination in employment. While the ILO and various countries (including Australia and New Zealand from within the region) have attempted to influence this direction, the most powerful pressures have come from North America and the European Union (EU), which have sought to link trading arrangements to human rights issues. Such pressures tend to be viewed with suspicion by governments in the region, at best as meddling in internal affairs, at worst as opportunistically forcing them to open up previously protected areas of their economies (Gilley 1998).

\section{Industrialisation, democratisation and convergence}

A long debated argument states that 'there is a global tendency for technological and market forces associated with industrialisation to push national employment relations systems towards uniformity or convergence'. ${ }^{2}$ We use this argument to help us compare employment relations in Asia-Pacific countries. Our first hypothesis is that as economies move towards becoming industrialised market economies (IMEs), their employment relations institutions and behaviour tend to converge on those that prevail in existing IMEs. Such direction includes the growing autonomy of employment relations institutions - including unions - and independent collective bargaining.

The rules, attitudes and behaviour of the parties in employment relations are also shaped by their political context. Against the background of assumptions about the consequences of democratisation, our second hypothesis is that major political changes, such as moves towards democratisation, will induce radical transformations in an economy's employment relations arrangements.

\section{Industrialisation}

Do the experiences of the Asia-Pacific region support these hypotheses, and if they appear to, which are the key explanatory factors? There has been a proliferation of commentaries, reports and academic writing which identifies the rapid industrialisation of the Asia-Pacific region and its emergence as a major geo-political entity (Borthwick 1992). While the regional economic crisis of the late 1990s highlighted the problems associated with entrenched relationship economies, 2 which in some cases

\footnotetext{
${ }^{2}$ This notion is of course controversial and subject to a range of criticisms; nevertheless, such a hypothesis can provide a useful way of helping to organise a discussion of comparative ER. See Kerr et al. (1973); Kerr (1983); Poole (1986) and Bamber and Lansbury (1998).
} 
tended to overshadow earlier economic successes, the second half of the $20^{\text {th }}$ century has been a period of rapid economic growth for many countries in the region.

While regional and supranational trading alliances, including the Association of Southeast Asian Nations (ASEAN) and the Asia-Pacific Economic Cooperation (APEC) forum, have emerged, the member countries are more heterogeneous and loosely grouped than EU countries. During the 1990s ASEAN countries attempted to introduce policies aimed at greater economic co-operation; however, economic problems and political differences have tended to hamper such moves. Explanations for the rapid industrialisation of many of the Asia-Pacific countries have variously drawn on socio-economic approaches, political 'strong state' explanations, neo-Confucian ethics and cultural 'collectivist' models (Verma et al. 1995:336). Rather than pursue cultural typologies, we follow an approach advocated by Dore (1979) and discuss the contexts for employment relations that may reflect the different stages of economic development that all these countries are passing through. Classifications may be somewhat arbitrary and there are many differences between the countries in each of the following categories, but a pattern is discernible and may facilitate discussion.

The first group includes the IMEs of Japan, New Zealand and Australia. Current reforms or structural adjustment programs in these countries are in part a response to the spread of industrialisation to other countries of the Asia-Pacific region. The second group, known as the 'Asian Tigers', includes the newly industrialised economies (NIEs) of South Korea and Taiwan. The 'Tigers' are clearly distinctive as post-Japan industrialisers and some of them moved towards the development of democratic institutions during the 1990s. The third group comprises the next generation of industrialisers and includes the People's Republic of China (PRC) and Indonesia. If it maintains the growth rates achieved throughout the 1990s, the PRC will achieve NIE status in the first few decades of the $21^{\text {st }}$ century. However, economic development in the PRC has been uneven, with growth rates in the special export zones (SEZs) greatly outstripping those of more isolated regions. Indonesia also achieved relatively high growth rates during the early to mid-1990s and had been expected to reach a higher level of industrial development by the early $21^{\text {st }}$ century. However, after being adversely affected by the Asian economic crisis, it faces a period of political and economic uncertainty as it enters the new millennium.

\section{Restructuring in Japan, Australia and New Zealand}

Many explanations for the extraordinary growth of several Asia-Pacific economies since the early 1960s, beginning with Japan (Fruin 1992), suggest that employment relations may make a significant contribution to economic growth. This raises questions of universality and cultural or national uniqueness, either prescriptively, as with Japan as No. 1: Lessons for America (Vogel 1980), or analytically, as a justification for the development of a field of comparative HRM (Boxall 1995).

\section{Japan: A post-1945 model}

Since the early 1980s, there has been substantial interest in Japanese management (e.g. Suzuki 1995) and in the transferability of Japanese management styles to North America and Europe (e.g. Oliver and Wilkinson 1992). Many studies have tended to oversimplify the Japanese model, focusing on the 'three pillars' typology of enterprise unionism, lifetime employment and seniority promotion. There is little exploration of the legal environment and the impact this has had on shaping Japan's industrial relations practices (cf. Tackney 2000). While employment relations in Japan are more complex than is demonstrated by the so-called 'three pillars' analogy (Kuwahara 1998), a consideration of other institutional sources of jurisprudence suggests that the concept of lifetime employment remains a broad institutionalised social norm.

Problems in the Japanese economy during the 1990s, and a subsequent rise in its unemployment rate, led to suggestions that the Japanese employment relations model was under severe strain and required substantial adjustment. As domestic demand fell during the 1990s, large Japanese firms reduced the working hours of employees and used redundancy as a last resort (Nitta 1998).

The Japanese 'model' of employment relations has been linked to Japan's high economic growth rates in the post-1945 era. The evidence suggests that changes during the 1990s tended to be cyclical rather than structural in nature. However, some factors, such as an ageing population, deregulation and moves towards a service dominated economy, suggested the model would need to 
adapt to exist more easily within the constraints of lower economic growth. Japan was becoming a mature IME.

\section{Australia: Towards decentralised bargaining}

Many of the moves towards employment relations reform in Australia during the 1990s reflected a perceived need by governments to improve the competitiveness of the work force. Changes in employment relations legislation, therefore, were often linked to notions of microeconomic reform.

From 1983 to 1996, the Australian polity was dominated by the Australian Labor Party (ALP). Its wage and prices 'Accord' with the Australian Council of Trade Unions (ACTU) was an important contributor to the ALP's electoral success at the federal level. The Accord broadly consisted of a trade-off whereby the ACTU agreed to moderate union pay claims and industrial action in exchange for a say in the determination of political, economic and industry policies. Consequently, there was an increase in the 'social wage' in terms of rights to health and safety at work, consultation, superannuation and the regulation of equal employment opportunities, redundancy and dismissal. In 1983, the Accord was intended to enable Australia to pull out of economic recession without inflationary increases in labour costs. After periodic revision, it came to form part of a broad framework of economic and social restructuring which emphasised microeconomic reform.

Legislation in 1988 simplified and standardised dispute settlement and required federal tribunal jurisdiction to take greater cognisance of the interests of the parties and the wider community (Frenkel 1993: 259). Further legislation in 1993 extended the challenged to the traditional Australian employment relations system by allowing for the ratification of non-union agreements. At the federal level, the move towards enterprise bargaining favoured by the ALP government and supported by the ACTU was slow, although several states enacted legislation during the 1990s to favour enterprise bargaining rather than follow the tradition of centralised arbitrated awards. ${ }^{3}$

Australia's post-1996 conservative coalition government claimed a mandate to further deregulate and reform employment relations in Australia and discontinue the previous (Labor) government's Accord with the unions. The Workplace Relations Act 1996 aimed to further decentralise the Australian employment relations system.. It included limiting the jurisdiction of centralised awards to twenty 'allowable matters' and promoting decentralised enterprise bargaining. Under the Act employees could negotiate collective (enterprise) agreements or individual contracts. Unlike the situation in New Zealand, the centralised award system was retained as a 'safety net' for employees not covered by any other agreement. However, at the time of writing, the coalition government is proposing a second-wave of reforms. If it succeeds in implementing most of its proposals, it will move Australia's federal industrial relations system closer to the current deregulated New Zealand model.

\section{New Zealand: From welfare state to radical reform}

Until the mid-1980s, New Zealand was regarded as a welfare state with a regulated labour market surrounded by tariff protection. Since then it has dismantled much of the welfare state and deregulated its labour market. After relatively rapid economic growth in the mid-1990s, the economic downturn brought on by the Asian financial crisis in the late 1990s has prompted further restructuring and public sector reforms. As in Australia, the change process was initiated by a perceived need in the New Zealand polity to improve the competitiveness of the economy. Begun by a Labour government, employment relations reform was continued and accelerated by subsequent non-Labour governments that appeared to adopt so-called rational economic policies that were similar to those of the UK's Prime Minister Thatcher and the US's President Reagan. However, the implementation of such policies was more thoroughgoing and less constrained in New Zealand than in the UK, the US or, for that matter, Australia due to New Zealand's relatively small population - less than four million and its unicameral, unitary and centralised legislative assembly.

\footnotetext{
${ }^{3}$ See Dabscheck (1995:100-104). In contrast with earlier British traditions of voluntary collective bargaining, Australian employment relationships have long been regulated by legally binding arbitrated industrial awards. An award is a legally enforceable determination of employment terms and conditions in a firm or industry, which has been arbitrated or certified by an IR commission. An award may apply at either a national, state, industry, enterprise, workplace and/or occupational level.
} 
A particularly significant event in this radical program was the deregulation of employment relations by the Employment Contracts Act 1991 which union critics have described as 'an employers' charter' (Anderson 1991). It abolished the Arbitration Court and the award system, de-emphasised collective bargaining and withdrew exclusive jurisdiction rights from unions (Deeks et al.1994; Walsh and Ryan 1993). The size and scope of unions have been severely curtailed so that many employers are no longer confronted by any effective countervailing power from unions and are more or less in a 'union-free' environment (Harbridge and Honeybone 1995).

\section{A comparison of Japan, Australia and New Zealand}

In the post-1945 era Japan generally achieved higher economic growth rates than either Australia or New Zealand, with some claiming that Japanese employment relations practices were a contributing factor. Japan was governed for most of this period by a single party, the Liberal Democratic Party (LDP) With the LDP closely aligned to big business, unions generally made little contribution to economic and social policy. Although a coalition containing the Japan Socialist Party was in office from 1994 to 1996, it resulted in only minor changes to the employment model.

In Australia, and even more so in New Zealand, there appears to have been a large-scale transformation in terms of employment relations since the early 1980s. These changes have not been driven by moves towards democratisation at the macro level. Rather, such changes have been induced by explicit political action by governments that were not significantly more or less democratic than their predecessors. While the Japanese model has been resilient, it has been affected by a maturing economy, an ageing population, an expanding service sector and pressures for deregulation. In the 1990s there was little evidence that it was converging on a Western model, although some practices were being modified. For instance, in 1999, after the car manufacturer Renault bought a stake in Nissan, a former icon for Japanese employment relations, practices moved towards adopting Westernstyle employment relations, including the use of extensive redundancies. The decisions to reform employment relations in Australia and New Zealand were partly a response to the economic growth of other countries in the region, including Japan, a response that helped to generate a perception of the need for microeconomic reform. Subsequent changes to labour markets were shaped by product market considerations and policies of so-called economic-rationalism.

\section{Newly Industrialising Economies (NIEs): South Korea and Taiwan (ROC)}

Industrialisation in the NIEs generally begins with the development of labour intensive industries, such as clothing, textile and footwear manufacturing, which allow such them to exploit their comparative low wage advantage. The next stage of economic development may be to follow move to heavy industries, such as steel making, shipbuilding and motor vehicle manufacturing, often facilitated by government 'soft' loans. The next move is towards high-tech 'knowledge intensive' industries, requiring a highly educated work force. One of the consequences for employment relations is the need for increasingly sophisticated HRM practices as countries attempt to move their economies along the value-added path.

\section{South Korea: Chaebol led development}

South Korea's rapid industrialisation saw its per capita GDP rise from US\$87 in 1962 to more than US\$10 000 in 1987 (Park and Leggett 1998: 275). During most of this period Korea was governed by a succession of strong authoritarian governments. There was a great deal of direct state intervention in the economy with economic development guided through the chaebol — large family run conglomerates. By the early 1990s the five top chaebol contributed approximately 60 per cent of South Korea's GDP (BOK 1990). Such a concentration of economic power and government influence was blamed for much of the corruption exposed in the late 1990s, resulting in the collapse of the Hanbo group. This alliance of an authoritarian government and big business meant that union jurisdiction was limited; until 1997 the FKTU was the only recognised official union confederation. To maintain Korea's competitive advantage in the export of labour intensive manufactured goods, successive governments tended to limit wage increases.

Following student-led large-scale protests, the 29 June Democratisation Declaration in 1987 began moves towards more liberal political institutions (Park and Park 2000). In this environment union membership grew rapidly, along with strikes and increased wage demands. While not officially 
recognised, there was an associated rapid growth in new independent trade unions. In 1995, a group of these merged to form the KCTU as a more radical alternative to the FKTU. These independent unions co-ordinated some notable large-scale industrial protests that attracted international media interest. The protests included those against the 1996 Labour Law amendments that relaxed restrictions on retrenching workers and against firms laying off workers during the Asian economic crisis of the late 1990s. Despite such public protests, union membership began to decline during the 1990s. This has been variously attributed to industrial restructuring and the growth of the services sector (Park and Leggett 1998: 280). Nevertheless, trade unions have become a more significant part of the South Korean polity.

Among the responses of the chaebol to increased worker demands has been that of seeking increased workforce flexibility. To assist in employment relations reform along these lines and to facilitate shifting the Korean economy towards more 'knowledge intensive' industries the government set up the multipartite Industrial Relations Reform Commission (IRRC) in 1996. In this scheme of things it has been possible to discern some firms seeking to introduce more participative management styles (Lee 2000).

Along with the above developments a major impetus for industrial restructuring and reform of employment relations came from the Asian economic crisis during the late 1990s. Following the regional economic turmoil, the South Korean currency devalued sharply, causing severe problems for firms exposed to offshore loans. Following its call on the International Monetary Fund (IMF) for assistance, the government initiated an austerity drive to implement the IMF conditions. It also set up a Tripartite Commission with representatives from both the FKTU and the officially not recognised KCTU to oversee the process of structural and employment relations reform.

While the crisis exposed problems associated with high debt servicing ratios in the chaebol, some observers saw the government's willingness to embrace the IMF recommendations as being partially politically motivated. President Kim Dae-Jung — elected in 1998 - had long campaigned against the concentrated of power of the chaebol and their downsizing and/or restructuring might result in a diminution of their economic and political power (Liew 1998). The lessening of chaebol influence could have major implications for South Korean employment relations. Being the country's major employers, the chaebol had developed employment relations policies and practices that influenced terms and conditions of employment in many other enterprises. Company towns such as Woosan (Hyundai) and, in the public sector, Pohang (POSCO), house and service large numbers of employees. Moves towards the creation of more small- to medium-sized enterprises could see a significant change in employment relations strategies.

\section{Taiwan: decentralised industrialisation}

During the 1980s and 1990s, Taiwan's political and economic landscape changed considerably. The legacy of a strong authoritarian government by the Kuomintang that had ruled Taiwan since the defeat of the mainland Chinese nationalists in 1949 gave way to a democratic and liberal approach. A maturing economy saw the growth of the service sector and moves towards the production of higher value-added, knowledge intensive goods. In contrast to Korea, where industrialisation was centred on the chaebol, small- and medium-sized firms have dominated the private sector in Taiwan. Many such firms had their origins as 'family-run' businesses governed by paternalistic employment relations practices.

Changes in the Taiwan economy required a better educated work force and created an awareness of a need for more sophisticated HRM. Government regulations, such as the Fair Labour Standards Law 1984, introduced wide-ranging and enforceable labour standards; however, the government attempted to promote a more voluntarist approach to employment relations in the 1990s. This was recognition in part of the need for increased flexibility in employment relations practices in a more open economy. At the same time, the internationalisation of the economy has included largescale Taiwanese investment in the PRC, with many Taiwan's managers having to learn new skills to manage mainland Chinese employees (Schak 1997).

Democratisation has in part led to the introduction of new social welfare legislation, such as unemployment insurance; however, its effect on the unions has been less clear. The growth of unionism in the services sector, traditionally difficult to organise, has been accompanied by a reduction in union membership in more traditional industries, and restrictions apply to organisation 
teachers and public sector employees. Unions, however, are more independent than under previous authoritarian governments and now more actively promote the welfare of their members. In response to a perceived increase in worker lay-offs, in part induced by the Asian economic crisis, the late 1990s saw the growth of independent, although technically illegal, unions. In 1997, recognition was not granted to a National Federation of Industrial Labor Unions (NFILU) formed by a breakaway from the officially recognised Chinese Federation of Labor (CFL). Although illegal as a federation, affiliates of a National Federation of of Independent Trade Unionists (NFITU) function legally as independent unions (US Department of State 1999: 895).

Employer responses to improved social welfare legislation include non-compliance and the substitution of subcontractors for employees. Employers have also put a greater focus on HRM to improve worker productivity, including improved training and incentive programs. Higher education requirements have resulted in many workers entering the workforce at a later age than previously. Thus, political changes in Taiwan appear to have led to increases in social welfare legislation that in turn have affected employment relations. At the same time, the quality of employment relations has been affected by the changing economic environment. While unions have achieved some independence, the growth of the service sector has been eroding their traditional base among industrial workers.

\section{South Korea and Taiwan compared}

These two NIEs exhibit some similarities. Both underwent rapid industrialisation under strong authoritarian governments after 1945, particularly from the 1960s. In the 1980s and 1990s both countries moved towards more democratic institutions and open economies. Changes also occurred due to employers reacting to changing product markets (and labour markets). Unions in both countries have become increasingly independent; however, moves away from manufacturing towards more service-based economies have been partly responsible for their declining memberships. In both countries restrictions remain on organising in the public sector.

A major difference between the two IMEs is the industrial concentration of their economies. While Korea's economy is dominated by the chaebol, Taiwan's rapid industrialisation has been largely achieved through the growth of small- to medium-sized firms. Thus, employment relations in South Korea were developed by the policies and practices of a relatively small number of large conglomerates. However, in Taiwan firms were often too small to develop sophisticated employment relations practices, which in part led to the government introducing wide-ranging 'generic' legislation through the Fair Labor Standards Law 1984. Enforcement of the law, however, was often ignored, especially before the onset of democratisation in the 1990s and remains limited due to a weak inspection authority.

\section{The People's Republic of China (PRC) and Indonesia}

The HRM practices and labour management policies of a third level of Asian industrialisers, including the PRC, have been attracting increased attention from scholars (O'Leary 1994; Jackson 1994; Kuruvilla and Arudsothy 1995). Echoing the experiences of the NIEs, the third level of countries can get caught in a 'sandwich trap' of cheap labour competition from below and exclusion from higher value-added markets from above (Deyo 1995:23). It is arguable that these market influences have outweighed trends towards democratisation in influencing the transformation of employment relations in these countries. Political developments in Indonesia since the fall of the Suharto government, however, have been accompanied by more militant worker demonstrations.

\section{The People's Republic of China (PRC): Towards 'market socialism'}

The economic reforms instituted by Deng Xiaoping in the late 1970s moved the direction of the Chinese economy away from its former Maoist doctrines. Foreign owned and domestic private enterprises appeared and in 1992 the goal of a 'socialist market economy' was announced. In China the central planning priorities determined the state level employment relations policies which shaped enterprise level employment relations practices. Subsequent reforms meant that 'the employment relations policies of Chinese enterprises are driven by product market considerations and by state-level employment relations policies which are being adjusted to a market-driven economy' (Verma and Yan 1995: 317-18). As employees have shifted from state-owned to privately-operated firms this has had 
profound effects on employment relations. Disputes arising from the rapid transfer of workers from 'lifetime' to contract employment appeared to provide the trigger for about 50 per cent of all labour disputes in the late 1980s and early 1990s; moreover, rural migration, in spite of restrictions, has created heavy urban unemployment (Jackson 1994). Structural reforms have been accompanied by large-scale lay-offs - about 17 million by the end of 1998 (Far Eastern Economic Review 18 February 1999: 12), and workers still employed were not getting paid. Worker grievances are not without protest and labour unrest is reported to be substantial but not mobilised (Far Eastern Economic Review 25 February 1999: 46-48).

While economic growth throughout the 1990s was relatively high, it was concentrated in the cities and special economic zones (SEZs) and Hong Kong. Attracted by the promise of jobs, many former rural workers migrated to the SEZs, but were paid substantially lower rates than local workers in similar industries; the practice of hiring workers from other regions was widespread (Hsing 1998). Piecework rates were common and municipal governments tended to turn a blind eye to minimum wage legislation, with local investment being a priority. Thus, the PRC provided some of the cheapest labour in the world to the factories being developed by entrepreneurs in the SEZs (O'Leary 1994: 51). There are between 60 and 70 million workers employed in the PRC's five SEZs and 14 'open cities' (Asian Labour Update May-July 1995). Approximately 80 per cent of SEZ workers are young, unmarried women who are housed in dormitories where working conditions are said to be poor, especially health and safety. Few workers are unionised and attempts to organise unions independently of the All China Federation of Trade Unions (ACFTU) are suppressed.

During the early 1990s a tripartite employment relations system was developed consisting of the Labour Ministry, the Chinese Enterprise Directors' Association (CEDA) and the ACFTU. The state maintains the upper hand in negotiations, with unions traditionally playing a supporting role by implementing state policy (Goodall and Warner 1997), but there are signs that unions are becoming more assertive (Ungar and Chan 1995).

China's transition towards a 'socialist market economy' with its associated employment relations changes has been relatively gradual. This has allowed state owned enterprises to soak up and/or retain workers who would otherwise become unemployed if a rapid transition to free market forces occurred. China's challenge, therefore, is to retrain such workers as the economy comes to be dominated by private firms (Ying and Warner 2000).

\section{Indonesia: Beyond the New Order?}

Following the destruction of the Indonesian Communist Party (PKI) by the New Order government of Suharto in the mid-1960s, Indonesian employment relations were strictly controlled by a strong authoritarian government, supported by the military. Cheap labour and compliant workforce was seen by the government as necessary for economic growth, and the failure by employers to pay minimum wages was routinely ignored (Gall 1998). The only union organisation recognised by the state - the SPSI - received much of its funding from the government, with military personnel appointed to many of its official positions. The government had linked Indonesian employment relations to the statesponsored doctrine of Pancasila. This includes notions of mutuality of interests, and of mutual respect and consultation between workers, employers and government (Lambert 1994: 87). In practice these notions appear rarely to have been achieved. While economic growth throughout the 1980s and early 1990s remained relatively high, working conditions, particularly for women, appeared to be harsh (ALU 1991).

Partly in response to the SPSI's perceived lack of effectiveness in representing worker interests, the 1990s witnessed the growth of independent unions that were not recognised by the state. The largest of these was the SBSI (Knowles 1993). While it has attracted international attention and support from agencies such as the ILO, SBSI leaders were subjected to government harassment and imprisonment.

The ending of the Suharto government amid the economic turmoil of 1998 left Indonesian employment relations at a crossroads. Moves towards the establishment of more democratic processes and institutions could help create greater government recognition for workers' groups and rights - as occurred in Korea after the 1987 democracy declaration. However, continuing political uncertainty, widespread economic problems and a legacy of vested interests make such a prospect difficult to predict with confidence. (Sutanto and Elliott 2000). 


\section{The PRC and Indonesia compared}

The PRC and Indonesia share some similarities. Both countries have large populations and strong authoritarian governments, although the New Order government in Indonesia has been fiercely anticommunist. In both countries the influence of the government on employment relations has overshadowed that of employer or worker groups and industrialisation has been achieved through the production of labour intensive goods - for the most part making use of comparatively low-cost labour.

Industrialisation in the PRC has not been accompanied by any significant moves towards democratisation. It remains a one party state with little government tolerance for political dissent. The greatest effect on employment relations in the PRC has been the rapid increase in privately-owned firms that require a highly committed, more productive work force.

Likewise, at least until the late 1990s, industrialisation in Indonesia was not accompanied by any significant moves towards more democratic institutions and processes. The Suharto government maintained a tight control over the labour movement, with little tolerance for labour dissidents. While Suharto's fall in 1998 was accompanied by calls for greater recognition for workers' organisations, political instability has made for an uncertain future. It remains to be seen how the post-1999 government will change employment relations arrangements in Indonesia.

\section{Conclusions}

Since World War II and especially since the early 1960s, several of the seven countries reviewed here recorded prolonged periods of high economic growth. A regional economic downturn in the late 1990s - often referred as the 'Asian crisis' - introduced some uncertainty about the prospects for the region in the $21^{\text {st }}$ century. The institutionalisation of employment relations and government policies on organised labour developed over a comparatively long period of time in the older IMEs of Australia and New Zealand. However, the rapid economic development in other countries in the region, particularly the NIEs, which include South Korea and Taiwan, prompted political and business leaders to develop such policies over a much shorter period.

We hypothesised first that, as economies move towards becoming industrialised market economies (IMEs), their employment relations institutions and behaviour tend to converge on those that prevail in existing IMEs. Do the experiences of the Asia-Pacific countries examined in this paper support this hypothesis? If they do, do technological, market or other forces appear to be key explanatory factors? Second, we hypothesised that major political change, such as moves towards democratisation, would induce radical transformations in an economy's employment relations.

Explanations of the political and industrial development of economies of the Asia-Pacific region vary. Many, in one way or another, associate democratisation and the phenomena of employment relations, including the institutions for resolving and regulating collective disputes of conventional employment relations and the behavioural science informed discipline and function for managing employees for the attainment of enterprise goals, known as HRM. Nevertheless, our preliminary observations of the countries examined in this paper show differing degrees of support for our hypotheses.

Among the established IMEs in the region, Japan developed an employment relations model that is quite distinct from Western IME models. The emergence of a non-LDP led coalition government in 1994 - the first non-LDP government for almost 50 years — did not radically change Japan's employment relations laws or institutions. In Australia and New Zealand, changes to employment relations practices were brought about by the perceived need for microeconomic reform in the face of international competition and changing product markets. These changes were hastened by the election of conservative governments in both countries. This has led to the introduction of less state-regulated employment relations systems, with the New Zealand approach having been more radical than that of Australia.

For the Asian NIEs, rapid industrialisation was accompanied by political change in the late 1980s and early 1990s. The introduction of more democratic institutions led to changes in the employment relations practices of both countries. In South Korea this was manifested in the rise of the independent union movement, while labour regulations in Taiwan were reinforced and expanded. 
However, there is little evidence that the employment relations of either of these countries are converging on a Western-style employment relations model.

Our review of the employment relations of the third level of industrialising countries in the Asia-Pacific region showed little support for either of our hypotheses. Strong authoritarian governments in the PRC and Indonesia have effectively controlled and guided employment relations policies in both countries. While industrialisation was not directly linked to moves towards democratisation, the economic turmoil in Indonesia in the late 1990s, brought on by the Asian crisis, helped cause the downfall of the Suharto government. This in turn led to calls for more democratic institutions.

The stimuli for change in employment relations, therefore, would appear to be more than a product of a country's level of industrialisation. Other factors include the dynamics of local and global product (and labour) markets and actions by governments to address microeconomic reform. Our examination of the above countries suggests that at a certain level of industrialisation, such as in the NIEs of South Korea and Taiwan, political liberalisation may follow economic liberalisation; however, we are cautious about making generalisations on the basis of just two countries.

Since product and labour markets and economic and political changes have not followed an unambiguous path of convergence, it is only to be expected that '...human resource management systems in the Pacific Region will differ in many ways' (Moore and Devereaux Jennings 1995: 5). We should not expect employment relations developments in the region to conform to models developed in Western IMEs. The industrialising Asia-Pacific economies are in many ways distinct social formations deserving of systematic analysis based on a growing body of research. Their responses to the economic challenges of the Asian crisis of the late 1990s will help shape regional employment relations institutions as we move into the new millennium.

\section{References}

Anderson, G (1991) 'The Employment Contracts Act 1991: An employers' charter?', New Zealand Journal of Industrial Relations 16: 127-42

Asian Labour Update (periodic) Asia Monitor Research Centre, Hong Kong.

Bamber, G J., Park, F, Lee, C, Ross, P and Broadbent, K (2000) eds Employment Relations in the Asia Pacific: Changing Approaches, Allen and Unwin, Sydney.

Bamber, G J. and Lansbury, R D. (1998) 'An introduction to international and comparative employment relations' in G J Bamber and R D Lansbury eds International and Comparative Employment Relations: A Study of Industrialised Market Economies, Allen and Unwin, Sydney.

Bamber, G J and Sappey, R B (1996) 'Industrial relations reform and organisational change: Towards strategic human resource management in Australia?' in B. Towers ed The Handbook of Human Resources Management, Blackwell, Oxford.

Benson, J (1996) 'Management strategy and labour flexibility in Japanese manufacturing enterprises', Human Resource Management Journal 6, 2: 42-55.

BOK (1990) Economic Indicators, Bank of Korea, Seoul.

Borthwick, M (1992) Pacific Century: The Emergence of Modern Pacific Asia, Westview Press, Boulder Colorado.

Boxall, P (1995) 'Building the theory of comparative HRM', Human Resource Management Journal 5, 5: 5-17.

Chaykowski, R P. and Verma, A (1992) Industrial Relations in Canadian Industry, Dryden, Toronto.

Clegg, H A. (1960) A New Approach to Industrial Democracy, Blackwell, Oxford.

Dabscheck, B (1995) The Struggle for Australian Industrial Relations Melbourne, Oxford University Press, Oxford.

Deeks, J, Parker, J and Ryan, R (1994) Labour and Employment Relations in New Zealand, Longman Paul, Auckland.

Deyo, F C (1989) Beneath the Miracle: Labor Subordination in the New Asian Industrialism, University of California Press, Berkeley Cal.

Deyo, F C (1995) 'Human resource strategies and industrial restructuring in Thailand' in S Frenkel and J Harrod eds Industrialization and Labor Relations: Contemporary Research in Seven Countries, ILR Press, Ithaca.

Dore, R (1973) British Factory, Japanese Factory: The Origins of National Diversity in Industrial Relations, Allen and Unwin, London.

Dore, R (1979) 'Industrial relations in Japan and elsewhere' in A M. Craig ed Japan: A Comparative View, Princeton University Press, Princeton NJ.

Dunlop, J (1993) Industrial Relations Systems, Harvard Business School Press, Boston Mass. 
Elgar, T and Smith, C (1994) Global Japanization, Routledge, London.

Elliott, F (1969) A Dictionary of Politics, Penguin, London.

Far Eastern Economic Review (weekly), Review Publishing, Hong Kong.

Farh, J L. (1995) 'Human resource management in Taiwan, the Republic of China' in L.F. Moore and P. Devereaux Jennings eds Human Resource Management on the Pacific Rim: Institutions, Practices and Attitudes, Walter de Gruyter Berlin.

Frenkel, S (1993) 'Australian trade unionism and the new social structure of accumulation' in S. Frenkel ed Organized Labor in the Asia-Pacific Region: A Comparative Study of Trade Unionism in Nine Countries, ILR Press, Ithaca N Y.

Fruin, M (1992) The Japanese Enterprise System, Oxford University Press, New York.

Gall, G (1998) 'Independent unionism in Indonesia' International Journal of Employment Studies 6, 1: 83-102.

Gardner, M and Palmer, G (1997) Employment Relations, Macmillan, Melbourne.

Gilley, B (1998) 'Buying binge' Far Eastern Economic Review (weekly) 20 August 1998, 161, 34: $42-44$.

Goodall, K and Warner, M (1997) 'Human resources in sino-foreign joint ventures: Selected case-studies in Shanghai, compared with Beijing', International Journal of Human Resource Management, 8, 5: 56994.

Gospel, H F and Palmer, G (1993) British Industrial Relations, Routledge, London.

Harbridge, R and Honeybone, A (1995) 'Trade unions under the Employment Contracts Act: Will the slimming be fatal?' in P Boxall ed The Challenge of Human Resource Management, Longman Paul, Auckland.

Harbridge, R and Moulder, J (1993) 'Collective bargaining and New Zealand's Employment Contracts Act: One year on', Journal of Industrial Relations 35, 1: 62-83.

Hsing, You-tien (1998) Making Capitalism in China: The Taiwanese Connection, Oxford University Press, New York.

Hutchings, K (1996) 'Workplace practices of Japanese and Australian multinational corporations operating in Singapore, Malaysia and Indonesia', Human Resource Management Journal 6, 2: 56-69.

Jackson, S (1994) 'Labour issues in China' in S. Jackson ed. Contemporary Developments in Asian Industrial Relations, Industrial Relations Research Centre, University of New South Wales, Sydney.

Katz, H C and Kochan, T A (1992) An Introduction to Collective Bargaining and Industrial Relations, McGrawHill, New York.

Kerr, C (1983) The Future of Industrial Societies: Convergence or Continuing Diversity? Harvard University Press, Cambridge Mass.

Kerr, C (1973) Industrialism and Industrial Man: The Problems of Labor and Management in Economic Growth, Penguin, London.

Kerr, C, Dunlop, J T, Harbison, F and Myers, C A (1975) Industrialism and Industrial Man, Penguin, London.

Kim, T (1995) 'Human resource management for production workers in large Korean manufacturing enterprises' in S Frenkel and J Harrod eds Industrialization and Labor Relations: Contemporary Research in Seven Countries, ILR Press, Ithaca NY.

Knowles, K (1993) 'A new era of workers' rights' Southland Magazine, 3: 14-15.

Kuruvilla, S and Arudsothy, P (1995) 'Economic development strategy, government labor policy and firm-level industrial relations practices in Malaysia' in A Verma, T A. Kochan and R D Lansbury eds Employment Relations in the Growing Asian Economies: A Summary, Routledge, London.

Kuwahara, Y (1998) 'Employment relations in Japan' in G J Bamber and R D Lansbury eds International and Comparative Employment Relations: A Study of Industrialised Market Economies, Allen and Unwin, Sydney.

Kwon, S H. and Leggett, C (1994) 'Industrial relations and South Korean chaebol' in R Callus and M Schumacher eds Current Research In Industrial Relations: Proceedings of the 8th AIRAANZ Conference February 1993, Sydney: 804-834.

Lambert, R (1994) 'Authoritarian state unionism in new order Indonesia' in R Callus and M Schumacher eds Current Research In Industrial Relations: Proceedings of the 8th AIRAANZ Conference February 1993, Sydney: 86-13.

Lee, J (2000) 'Changing approaches to industrial relations in Taiwan' in Bamber, G J., Park, F, Lee, C, Ross, P and Broadbent, K ed Employment Relations in the Asia Pacific, Allen and Unwin, Sydney.

Lee, J S and Park, Y B (1995) 'Employment, labor standards and economic development in Taiwan and Korea', Labor, Special Issue Tenth IIRA World Congress May 31-June 4: 223-42.

Liew, L (1998) 'A political economy analysis of the Asian financial crisis', Journal of Asian Political Economy 3, 3: 301-30.

Mathews, J (1994) Catching the Wave: Workplace Reform in Australia, Allen and Unwi, Sydney.

Moore, L F and Devereaux Jennings, P eds (1995) Human Resource Management on the Pacific Rim: Institutions, Practices, and Attitudes, Walter de Gruyter, Berlin. 
Nitta, M (1998) 'Employment relations after the collapse of bubble economy' in J Banno ed The Political Economy of Japanese Society Vol. 2, Oxford University Press, Oxford.

OED (1973) The Shorter Oxford English Dictionary on Historical Principles, Clarendon Press, Oxford.

O'Leary, G (1994) 'The contemporary role of Chinese trade unions' in S Jackson ed Contemporary Developments in Asian Industrial Relations, Industrial Relations Research Centre, University of New South Wales, Sydney.

Oliver N and Wilkinson B (1992) The Japanisation of British Industry, Blackwell, Oxford.

Paik, Y, Vance, C and Stage, D (1996) 'The extent of divergence in human resource practice across three Chinese national cultures: Hong Kong, Taiwan and Singapore', Human Resource Management Journal 6, 2: 18-29.

Park, F and Park, Y (2000) 'Industrial relations reform and financial crisis in Korea' in Bamber, G J, Park, F, Lee, C, Ross, P and Broadbent, K eds Employment Relations in the Asia Pacific, Allen and Unwin, Sydney.

Park, Y and Leggett, C (1998) 'Employment relations in Korea' in G J Bamber and R D Lansbury eds International and Comparative Employment Relations: A Study of Industrialised Market Economies, Allen and Unwin, Sydney.

Poole, M (1986) Industrial Relations: Origins and Patterns of National Diversity, Routledge, London.

Poon, T (1996) 'Dependent development: The subcontracting network in Hong Kong and Taiwan compared', Human Resource Management Journal 6, 2: 38-49.

Roberts, H S (1986) Roberts' Dictionary of Industrial Relations (prepared by Industrial Relations Centre, University of Hawaii at Manoa), The Bureau of National Affairs, Washington, DC.

Schak, D C (1997) 'Taiwanese labour management in China', Employee Relations: The International Journal 19, 4 and 5: 365-73.

Sender, H (1998) ‘Asian indigestion', Far Eastern Economic Review (weekly), 1 October 1998.

Sutanto, S and Warner, M (2000) 'The development of Indonesia's industrial relations' in Bamber, G J, Park, F, Lee, C, Ross, P and Broadbent, K ed. Employment Relations in the Asia Pacific, Allen and Unwin, Sydney.

Suzuki, S (1995) 'Tradition and modernity in Japanese management: On industrialization and the groupism management in Japan' in A Hing, P Wong, and G Schmidt eds Cross Cultural Perspectives of Automation,: Sigma, Berlin.

Tackney, C T (2000) 'The legal environment of the Japanese industrial relations system' in Bamber, G J, Park, F, Lee, C, Ross, P and Broadbent, K ed. Employment Relations in the Asia Pacific, Allen and Unwin, Sydney.

US Department of State (1999) Country Reports on Human Rights Practices for 1998, US Gopvernment Printing Office, Washington DC.

Ungar, J and Chan, A (1995) 'China, corporatism and the East Asian model', Australian Journal of Chinese Affairs 33 (January): 29-53.

Verma, A, Kochan, T A and Lansbury, R D eds (1995) 'Lessons from the Asian experience', Employment Relations in the Growing Asian Economies: A Summar, Routledge, London.

Verma, A and Yan, Z (1995) 'The changing face of human resource management in China: Opportunities, problems and strategies' in A Verma, T A Kochan and R D Lansbury Employment Relations in the Growing Asian Economies, A Summary, Routledge, London.

Vogel, E F (1980) Japan as No. 1: Lessons for America, Charles E. Tuttle, Tokyo.

Wager, T and Gilson, C (1996) 'Workforce reduction in Australia and New Zealand', Human Resource Management Journal 6, 2: 86-96.

Walsh, P and Ryan, R (1993) 'The making of the Employment Contracts Act' in R Harbridge ed Employment Contracts: New Zealand Experiences, Victoria University Press, Wellington.

Warner, M (1996) 'Human resources in the People's Republic of China', Human Resource Management Journal 6, 2: 30-41.

Wilkinson, B (1994) Labour and Industry in the Asia-Pacific: Lessons from the Newly-Industrialised Countries, Walter de Gruyter, Berlin.

Wright, C (1995) The Management of Labour: A History of Australian Employers, Oxford, Melbourne University Press.

Ying, Z and Warner, M (2000) 'Employment relations with "Chinese characteristics"' in Bamber, G J, Park, F, Lee, C, Ross, P and Broadbent, K ed Employment Relations in the Asia Pacific, Allen and Unwin, Sydney 
Bamber \& Leggett 